\title{
Prorocentrum bimaculatum sp. nov. (Dinophyceae, Prorocentrales), a new benthic dinoflagellate species from Kuwait (Arabian Gulf)
}

\author{
Nicolas Chomérat ${ }^{1,{ }^{*}}$, Maria Saburova ${ }^{2}$, Gwenaël Bilien $^{1}$, Faiza Al-Yamani ${ }^{3}$
}

\begin{abstract}
${ }^{1}$ IFREMER, Station de Concarneau, place de la Croix, 29900 Concarneau, France
2 Institute of Biology of the Southern Seas, Pr. Nakhimova, 2, 99011, Sevastopol, Ukraine Kuwait Institute for Scientific Research (KISR), Oceanography and Fisheries Research Program, Aquaculture, Fisheries and Marine Environment Dept., P.O. Box 1638, 22017 Salmiya, Kuwait

${ }^{3}$ Kuwait Institute for Scientific Research (KISR), Oceanography and Fisheries Research Program, Aquaculture, Fisheries and Marine Environment Dept., P.O. Box 1638, 22017 Salmiya, Kuwait
\end{abstract}

*: Corresponding author : Nicolas Chomérat, email address : $\underline{\text { nicolas.chomerat@ifremer.fr }}$

\begin{abstract}
:
A new benthic dinoflagellate species, Prorocentrum bimaculatum sp. nov., is studied from Kuwait's marine sediments, based on detailed morphological and molecular data. Cells are large, oblong oval in shape. They are $49.9-55.3 \mu \mathrm{m}$ long and $38.4-43.2 \mu \mathrm{m}$ wide. The ornamentation of this new species is peculiar, and characterized by smooth valves with large pores $(0.32-0.50 \mu \mathrm{m})$ scattered on their surface, except in two circular patches of $\sim 15 \mu \mathrm{m}$ in diameter, devoid of ornamentation and located on both sides of the valve centers. The periflagellar area is widely triangular, located in a moderate excavation of the right valve, and comprises nine platelets. The intercalary band of $P$. bimaculatum is smooth. The molecular phylogenetic position of this new taxon was inferred from SSU and LSU rDNA genes. In both phylogenetic analyses, $P$. bimaculatum branched with high support with Prorocentrum consutum and formed a clade sister to the one including $P$. lima and related species such as $P$. arenarium, $P$. belizeanum, $P$. hoffmannianum, and $P$. maculosum. From the phylogenetic study, since most species related to $P$. bimaculatum are known for their toxic effects and production of okadaic acid, this new species can be considered as a potential toxin producer, but this has to be analyzed.
\end{abstract}

Keywords : Arabian Gulf ; benthic dinoflagellates ; Kuwait ; molecular phylogeny ; morphology, nuclear DNA ; Prorocentrum ; rDNA ; SEM ; taxonomy

Abbreviations: bp, base pairs ; ML, maximum likelihood ; MP, maximum parsimony ; BI, Bayesian inference 
41 Members of the genus Prorocentrum Ehrenberg constitute a diverse group of marine microalgae with a wide geographical distribution and can contribute a considerable part to benthic dinoflagellate assemblages, especially in sub-tropical and tropical areas (e.g. Faust 1990, Faust 1993a, Faust 1993b, Faust 1994, Faust and Gulledge 2002, Mohammad-Noor et al. 2007b). Many Prorocentrum species have been found to produce okadaic acid and can cause diarrhetic shellfish poisoning (DSP) (Faust and Gulledge 2002).

Studies of marine microalgae in Kuwait's marine environment were focused more on the diversity of plankton community than on the composition of benthic species. The diversity of benthic dinoflagellates of Kuwait has been recently reported (Saburova et al. 2009, AlYamani and Saburova 2010a, b, Polikarpov et al. 2010) and 58 dinoflagellate taxa were documented during these investigations. Members of the genus Prorocentrum were among the most diverse thecate dinoflagellates in this environment. Eight benthic Prorocentrum species recorded from Kuwait to date are $P$. arenarium Faust, $P$. concavum Fukuyo, $P$. consutum Chomérat et Nézan, $P$. emarginatum Fukuyo, $P$. fukuyoi Murray et Nagahama, $P$. lima (Ehrenberg) Stein, P. norrisianum Faust et Morton, and P. rhathymum Loeblich III et al. Among them, five species can be considered as potentially toxic. The cosmopolitan species $P$. fukuyoi is widely distributed throughout Kuwait's intertidal sandflats, and it may be the most abundantly occurring species of all thecate dinoflagellates. Recently described from temperate area (Chomérat et al. 2010), P. consutum was found to co-occur with P. fukuyoi in subtropical Kuwait's intertidal sediments, but at a low abundance.

During the course of our studies on the populations of $P$. consutum from Kuwait's intertidal sediments, we found a Prorocentrum species with a very characteristic morphology. It was rather similar to P. consutum in size and shape, but it differed in the original pattern of valve pores from not only $P$. consutum but also from all other currently described 
Prorocentrum species. Thus, the aim of this paper is to describe this new species on the basis of light and scanning electron microscopical observations and molecular phylogenetic data.

\section{Material and Methods}

\section{Sampling}

Kuwait's marine environment is generally shallow with broad flats to the north and a gentle to steep shelf slope along the southern coastline. Height differences of Kuwait's mixed, semidiurnal tides from low-low water to high-high water are 3.5 to $4 \mathrm{~m}$, and horizontal distances between extreme tidal heights may exceed $8 \mathrm{~km}$ in Kuwait Bay. Mean annual temperature of Kuwait's surface water is $23.8^{\circ} \mathrm{C}$, with maximum in July and August, when it ranges from $30.5^{\circ} \mathrm{C}$ up to $36^{\circ} \mathrm{C}$ in shallow waters of Kuwait Bay; temperature minimum coincides with January and February $\left(14^{\circ} \mathrm{C}\right.$, down to $\left.11.9^{\circ} \mathrm{C}\right)$. The mean annual salinity of this area of the Arabian Gulf is 41.6 psu (Al-Yamani et al. 2004).

The extended seashore of Kuwait is primarily composed of expansive intertidal flats, which range gradually from mud and sandy mud in the north to medium- or coarse-grained and organically depleted sediments along the southern part of Kuwait's coast. Study of benthic dinoflagellates was undertaken throughout Kuwait's coast from the southern part of Kuwait Bay up to the Saudi border on the south, however, dinoflagellate assemblages with presence of P. bimaculatum were recorded only from two sampling sites (Fig. 1) in May-June 2010. Site 1 is a small town beach, which is located just outside Kuwait Bay $\left(29^{\circ} 20^{\prime} 26^{\prime \prime} \mathrm{N}\right.$, $\left.48^{\circ} 05^{\prime} 49^{\prime \prime} \mathrm{E}\right)$. Intertidal sediments are composed of rather fine sands with less content of organic matter. Site 2 is located at the southern coast of Kuwait $\left(28^{\circ} 46^{\prime} 58^{\prime \prime} \mathrm{N}, 48^{\circ} 17^{\prime} 40^{\prime \prime} \mathrm{E}\right)$. Rather slopping intertidal sandflat is composed of medium- to large-grained and organically depleted sediments. 
Intertidal sediments were collected by sampling the upper sediment layer $(0-2 \mathrm{~cm})$

90 from sandy flats, which were exposed at low tide at different intertidal heights using plastic tube corers or flat spoon. The collected samples were transported directly to the laboratory, where dinoflagellates were separated from the sandy sediment by extraction using the frozen seawater method (Uhlig 1964), with a $110 \mu \mathrm{m}$ mesh size. A part of living material was preliminary observed with a Leica DMIL inverted microscope (Leica, Wetzlar, Germany) at $\times 35$ to $\times 200$ magnifications while a subsample was preserved with $4 \%$ neutral Lugol's solution and used for further examinations and molecular analyses.

\section{Light and scanning electron microscopy}

Living cells were observed and photographed using a Leica DMLM (Leica, Wetzlar, Germany) microscope fitted with a Leica DFC 320 digital camera. For detailed observations, individual cells fixed in Lugol's solution were isolated from field samples and washed in distilled water using a micropipette under an Olympus IX51 (Olympus, Tokyo, Japan) inverted microscope. Fixed cells were examined in light microscopy with an Olympus BX51 upright microscope equipped with epifluorescence (100W short arc mercury lamp), Nomarski Differential Interference Contrast (DIC) optics and a DP72 digital camera (Olympus). To visualize nuclei, cells were stained for $30 \mathrm{~min}$ with 4',6-diamidino-2-phenylindole, dihydrochloride (DAPI, Sigma) fluorochrome (final stain concentration $0.05 \mu \mathrm{g} \mathrm{ml}^{-1}$ ) and observed in epifluorescence using an Olympus U-MWU2 fluorescence cube (330-385 nm band pass excitation filter, $400 \mathrm{~nm}$ dichromatic beam splitter and $420 \mathrm{~nm}$ barrier emission filter).

For scanning electron microscopy (SEM), cells were individually isolated and concentrated in $0.2 \mathrm{ml}$ tubes containing distilled water and a drop of formaldehyde to prevent fungal development. Cells were filtered using polycarbonate membrane filters (Millipore 
114 GTTP Isopore, $0.22 \mathrm{~mm}$ pore size), rinsed in deionized water and prepared according to

115 Chomérat and Couté (2008). The examination was performed with a Quanta 200 (FEI,

116 Eindhoven, the Netherlands) scanning electron microscope with an electron acceleration of 5 $117 \mathrm{kV}$.

118 Cell dimensions were measured on 8 specimens: one specimen was measured in LM 119 using a calibrated micrometer on the eyepiece, while SEM digital micrographs of seven 120 specimens were processed with ImageJ software (Rasband 1997-2006). SEM photographs 121 were presented on a dark gray background using Adobe Photoshop CS2, v. 9.0.2 (Adobe 122 Systems, San Jose, CA, USA).

\section{DNA amplification and sequencing}

125 After their identification in LM, single cells were isolated from a field sample collected in May 2010 at Site 1 using a micropipette, under an IX51 inverted microscope and transferred onto a glass slide. Each cell was rinsed individually in several drops of double distilled water and then transferred to $0.2 \mathrm{ml} \mathrm{PCR}$ tube containing $5 \mu \mathrm{l}$ of $\mathrm{ddH}_{2} \mathrm{O}$. Then, PCR tubes were stored at $-20^{\circ} \mathrm{C}$. For PCR, the samples were thawed and 25 pmol of each primer and $12.5 \mu 1$

130 of PCR Master Mix 2X (Promega, Madison, WI, USA) containing the Taq DNA polymerase, dNTPs, $\mathrm{MgCl}_{2}$ and reaction buffers, were added in each tube. Two rounds of PCR were realized and $1 \mu \mathrm{l}$ of the dilution $\left(1 / 100\right.$ in $\left.\mathrm{ddH}_{2} \mathrm{O}\right)$ of the PCR product was used as a DNA

133 template for the second round of PCR. Almost the full length of the SSU rDNA $(\approx 1800$ base 134 pairs) was acquired for isolated cells of $P$. bimaculatum and also $P$. consutum from the same 135 sample.

The polymerase chain reactions for both rounds were performed in a TProfessional

137 Basic thermocycler (Biometra $\mathrm{GmbH}$, Goettingen, Germany) as follows: one initial 138 denaturating step at $94{ }^{\circ} \mathrm{C}$ for $2 \mathrm{~min}$, followed by 45 cycles each consisting of $94{ }^{\circ} \mathrm{C}$ for 30 
sec, $54{ }^{\circ} \mathrm{C}$ for $30 \mathrm{sec}$, and $72{ }^{\circ} \mathrm{C}$ for $4 \mathrm{~min}$, and a final elongation of $72{ }^{\circ} \mathrm{C}$ for $5 \mathrm{~min}$. The PCR

140 products were purified using the Wizard SV Gel and PCR Clean-up system (Promega)

141 according to the manufacturer's recommendations. The sequencing reaction was realized

142 using the ABI PRISM BigDye Terminator Cycle Sequencing Kit (Applied Biosystems,

143 Carlsbad, CA, USA) and the sequences were determined using an automated 3130 genetic

144 analyser (Applied Biosystems).

Sequences alignment and phylogenetic analyses

147 The SSU and LSU rDNA sequences obtained were aligned with other putative Prorocentrum

148 species and two outgroup (Scrippsiella spp.) sequences using MUSCLE algorithm (Edgar

149 2004) followed by refinement by eye with MEGA software (Tamura et al. 2007), version 4.

150 Genbank accession numbers of all sequences used are available in the supplementary material 151 (Appendix S1).

Evolutionary models were examined for each data set using maximum likelihood

153 (ML), Bayesian inference analysis (BI) and maximum parsimony (MP). The evolutionary

154 model and parameters were selected using jModelTest version 0.1.1 (Posada 2008).

155 According to Akaike information criterion (AIC) and Bayesian information criterion (BIC), a

156 general time reversible (GTR) model with a gamma correction $(\Gamma)$ for among-site rate

157 variation and invariant sites was chosen for the SSU dataset while a Tamura-Nei (TN93)

158 model with no invariant sites was chosen for the LSU dataset.

159 Maximum likelihood analyses were performed using PhyML version 3.0 (Guindon 160 and Gascuel 2003), Bayesian analyses were run using Mr Bayes version 3.1.2 (Ronquist and

161 Huelsenbeck 2003) and parsimony analyses with heuristic search were performed using

162 PAUP* version 4.0b for Windows (Swofford 2002). Bootstrap analysis (1000

163 pseudoreplicates) was used (for ML and MP) to assess the relative robustness of branches 
164 (Felsenstein 1985). Initial Bayesian analyses were run with a GTR model (nst=6) with rates

165 set to invgamma (gamma for LSU dataset). Each analysis was performed using four Markov 166 chains (MCMC), with two millions cycles for each chain. Trees were saved every 100 cycles 167 and the first 2000 trees were discarded. Therefore, a majority-rule consensus tree was created 168 from the remaining 18000 trees in order to examine the posterior probabilities of each clade.

169 The consensus trees were edited using MEGA 4 software. The two Scrippsiella 170 species were used to root the trees. The best ML phylograms are shown with robustness 171 values for each node (ML/BI/MP).

\section{Results}

174 Observations

175 Prorocentrum bimaculatum Chomérat et Saburova sp. nov. (Figs 2-21)

176 Descriptio: Organismus unicellularis, photosyntheticus et ovalis. Longitudo: 49.9-55.3 $\mu$ m;

177 latitudo: 38.4-43.2 $\mu \mathrm{m}$. Nucleus in medio-posteriori parte locatus et castaneae similis.

178 Valvae laeves cum poris dispersis praeter in duabus circularibus regionibus cum $15 \mu m$

179 diametro utrinque valvae centro locatis. Pori marginales in continuo annulo dispositi in

180 duabus valvis. Pori diameter: 0.32-0.50 $\mu \mathrm{m}$. Valva recta indentata in apice; valva sinistra

181 cum brevi apicali crista. Regio periflagellaris cum novem parvis lamellis constituta; aliquae

182 parvae lamellae utraequae ex parte tectae et conspicuae solum ex parte. Porus flagellaris

183 ovalis. Accessorius porus ovalis sed in apicale visu dissimulatus. Fascia intercalaris laevis.

185 Unicellular and photosynthetic organism, oval in shape. Length: $49.9-55.3 \mu \mathrm{m}$; width: $38.4-$ $18643.2 \mu \mathrm{m}$. Nucleus roughly chestnut-shaped, located in medio-posterior part of the cell. Valves 187 smooth with scattered pores, except in two circular areas of $15 \mu \mathrm{m}$ in diameter, located on 188 both sides of the valves centre. Marginal pores present on both valves. Pore size: $0.32-0.50$ 
$\mu \mathrm{m}$. Right valve with a moderate excavation at the apex; left valve with a short apical ridge.

190 Periflagellar area composed of nine platelets; some platelets overlapping others and being

191 only partially visible. Flagellar pore oval. Accessory pore oval but hidden in apical view.

192 Intercalary band smooth.

194 Habitat: marine and benthic

195 Holotype: Figs 8, 10, 11, SEM stub CEDiT2010H6 stored at the CEDiT (Centre of

196 Excellence for Dinophyte Taxonomy) dinoflagellate type collection, Wilhelmshaven,

197 Germany.

198 Isotypes: Figs 9, 11, 15. (SEM stub CEDiT2010I7).

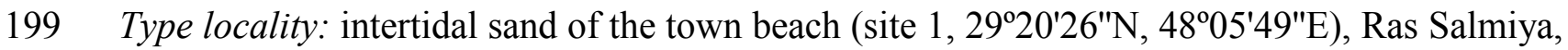

200 Kuwait.

201 Known distribution: P. bimaculatum was collected from Kuwait's intertidal sediments.

202 Etymology: From Latin, bis, two and maculatus, spotted, in reference to the two circular areas 203 without ornamentation, like two round patches on the valves.

204

205 The cells are large, 49.9-55.3 $\mu \mathrm{m}$ long (mean 52.5, SD 2.1, $n=8$ ) and 38.4-43.2 $\mu \mathrm{m}$ wide 206 (mean 40.9, SD 1.9, $n=8$ ) in valve view. They are oblong oval, with a length to width ratio 207 ranging from 1.25 to 1.32 (Figs 2-9, 18-19), and flattened (ca. $22 \mu \mathrm{m}$ broad in sagittal 208 suture/intercalary band view). In valve view, the anterior end of the right valve is indented 209 and has a wide V-shaped depression while the left valve forms a slight depression at the apex 210 (Figs 2-3, 6-9, 18-19). The valves are flat to slightly concave in their centre (Fig. 10). The 211 valve surface is smooth with large pores or deep depressions $(0.32-0.50 \mu \mathrm{m}$ in diameter $)$ 212 scattered. A continuous ring of marginal pores runs alongside the periphery of valves (Figs 8213 12). The pores form a characteristic pattern on the right and left valves. Two large circular 
214 areas (ca. $15 \mu \mathrm{m}$ in diameter) are devoid of pores, on both sides of the center of each valve 215 (Figs 6-7, 8-9, 11, 16, 18-19). This characteristic has been chosen to name the species, since 216 the valves appear to possess two unornamented patches on their surface. The inside valve 217 surface is smooth, and many pores seem to be grouped by two (Fig. 15), which was not seen 218 in the external view. The intercalary band is smooth (Fig. 12). The periflagellar area is widely triangular, about $8 \mu \mathrm{m}$ long and $4.5 \mu \mathrm{m}$ high, and located in a moderate excavation of the right valve (Figs $8,11,13)$. In apical view, this area is complex and comprises several platelets but some are obscured from view because of the extensions formed by some platelets (Fig. 13). Consequently, only the flagellar pore is partially visible (Fig. 13). Thanks to the observation of the periflagellar area from the inside of a right valve, nine platelets have been identified and named according to Taylor's scheme (Taylor 1980) (Fig. 14). Four platelets "a 1 ", “d”, "f", and "h" border the small apical ridge formed by the left valve (Figs 13, 20), while three other platelets " $\mathrm{a}_{2}$ ", "e" and "g" are located on the end of the V-shape (Figs 13-14, 20-21). The flagellar pore is surrounded by the platelets "c", "f", "g" and "e" (Figs 14, 21). It is oval and measures about $1.9 \mu \mathrm{m}$ in length and $1.2 \mu \mathrm{m}$ in width (Fig. 14). The accessory pore is totally hidden in apical view because of extensions of the platelets " $a_{1}$ ", ' $a_{2}$ " and "d", but it is present and clearly visible in the internal view (Fig. 14). It is oval, $1.1 \mu \mathrm{m}$ long and $0.7 \mu \mathrm{m}$ wide (Fig. 14). The platelet " $\mathrm{b}$ " and the major part of "c", which is the unique platelet separating the flagellar and accessory pores, are hidden in the apical view but seen in the view from the inside (Fig. 14). The platelets visible apically are ornamented with deep depressions (Fig. 13). of pores are observed in the valve center, between the two round patches (Fig. 17). The large pores have the same size than those observed in older cells, and the small pores are $0.14-0.17$ $\mu \mathrm{m}$ (Fig. 17). 
On living cells, the nucleus is difficult to observe because of the granulated cell 240 content (Figs 2-3). On fixed specimens, it is obscured because of the coloration resulting 241 from the fixation by Lugol's solution (Fig. 4). After DAPI-staining and observation in 242 epifluorescence microscopy, the nucleus appears to be roughly chestnut-shaped, and located 243 posteriorly below the centre of the cell (Fig. 5).

244 Prorocentrum bimaculatum was found in Kuwait's sediments, in association with 245 other Prorocentrum species such as $P$. fukuyoi and P. consutum but at a very low abundance.

Sequence analysis and molecular phylogeny

248 Five identical sequences of SSU rDNA (1789 bp) were acquired from independent cells of $P$. 249 bimaculatum and two identical sequences were obtained for LSU rDNA (974 bp), 250 corresponding to the D1-D3 domains. In addition, two identical sequences of SSU rDNA were acquired from two isolated cells of $P$. consutum to ensure the identification of this 252 species.

The phylogenetic trees inferred from SSU and LSU rDNA showed the existence of 254 two major lineages in the genus Prorocentrum identified as clade 1 and clade 2 in the 255 phylograms (Fig. 22). The clade 1 comprised asymmetric species, or those with a variable 256 morphology, including P. dentatum Stein, P. donghaiense Lu, P. emarginatum, P. fukuyoi, $P$. 257 glenanicum Chomérat et Nézan, $P$. gracile Schütt, $P$. mexicanum Osorio-Tafall, $P$. micans 258 Ehrenberg, P. minimum (Pavillard) Schiller, $P$. panamense Grzebyk et al., $P$. 259 pseudopanamense Chomérat et Nézan, P. triestinum Schiller, P. tsawwassenense Hoppenrath 260 et Leander and $P$. rhathymum (Fig. 22). The new species $P$. bimaculatum was included in 261 clade 2 which comprised the symmetric species $P$. arenarium, $P$. belizeanum Faust, $P$. consutum, P. concavum (including the synonym P. arabianum), P. faustiae Morton, $P$. 
hoffmannianum Faust, P. levis Faust et al., P. lima, P. maculosum Faust and unidentified 264 species "FL3" and "RAV2" (Fig. 22).

The SSU sequence of $P$. consutum from Kuwait grouped with a high statistical support

266 with the sequence from Brittany. The branches of nearly equal lengths indicated that they 267 hardly differ and that they unambiguously belong to the same taxon (Fig. 22A). In 268 phylogenies inferred from the two ribosomal genes, Prorocentrum bimaculatum formed a 269 sister-clade to that of $P$. consutum. In the SSU rDNA phylogeny, this position was supported 270 with a high posterior probability (BI) but with weaker values in ML and MP (Fig. 22A) which contrasts with in the LSU phylogeny where it was fully supported (Fig. 22B). Considered together, $P$. consutum and $P$. bimaculatum formed a sister group to the subclade containing $P$. 273 lima and related species, including P. arenarium, P. belizeanum and P. hoffmannianum. In the 274 LSU phylogeny, this position was fully supported with bootstraps values of 100 (ML and MP) and a posterior probability of $1.00(\mathrm{BI})$, whereas the support was weaker in the SSU phylogeny as only the posterior probability was 1.00 (Fig. 22).

\section{Discussion}

279 In this study, we examined morphological and molecular genetic characters of $P$. bimaculatum, a large and peculiar Prorocentrum species found in Kuwait's intertidal sediments. Both morphological and molecular data prove unambiguously that it corresponds to a new taxon. Morphologically, its ornamentation is very peculiar, with two circular areas 283 devoid of pores on each valve. Several species are devoid of ornamentation and thecal pores 284 in the center of valves (Table 1). In contrast, in P. bimaculatum some pores are found in the 285 central area between the two circular patches located on both sides of the centre, which differs 286 from all the other Prorocentrum species known. Among benthic Prorocentrum species, $P$. 287 bimaculatum is a rather large species, exceeding $50 \mu \mathrm{m}$ in length and thus only slight smaller 
than $P$. consutum and P. belizeanum (Table 1). This new species is related to P. consutum, $P$.

289 arenarium and $P$. lima in having smooth valves bordered by a row of marginal pores (Table

290 1). From a very recent study, $P$. arenarium has been found to be a synonym of $P$. lima and

291 corresponds to a round morphotype of this species, which means that the outline shape of a 292 taxon is probably not a good taxonomic criterion (Nagahama et al. 2011). The smooth 293 intercalary band observed in P. bimaculatum is characteristic of other Prorocentrum species, 294 such as P. belizeanum, P. foraminosum Faust, P. lima, and P. arenarium (Faust et al. 2008). In contrast with all these species, the presence of two kinds of pores in P. bimaculatum 296 has been noticed on one recently divided cell. Two sizes of thecal pores have been described 297 in several species such as $P$. caribbaeum Faust, $P$. emarginatum, $P$. rhathymum, $P$. formosum 298 Faust, P. fukuyoi, P. elegans Faust and P. tsawwassenense. Most of these species have an 299 asymmetrical morphology and belong to the clade 1 of Prorocentrum in phylogenetic studies. 300 Species of the clade 2 which are symmetric and mostly benthic have been reported with only 301 one kind of pores, either large as in P. lima, or small as in P. consutum. However, it is 302 remarkable that the smaller pores were only observed in a cell with a thin theca, while most of 303 other specimens were found to have large pores only. From this observation, small pores 304 could appear to be temporary during the cell development and they may clog or disappear 305 when the cellulosic theca thickens. The role of these pores is unknown yet.

307 an insertion in a moderate excavation of the right valve and the presence of a short apical 308 ridge of the left valve, which is also found in other species such as $P$. belizeanum, $P$. 309 consutum, P. hoffmannianum, P. sabulosum Faust, and P. reticulatum Faust. However, an 310 apical ridge lacks in $P$. arenarium, $P$. lima and $P$. maculosum. Since the extension of some 311 platelets hide a part of the periflagellar area in SEM, it was necessary to study this small area 312 from the inside of the cell. The use of sectioning and TEM (Mohammad-Noor et al. 2007a) 
could be used as a useful alternative method to complete these observations but it would be

314 difficult with only a few cells from an environmental sample fixed in Lugol and a culture would be required. The number and arrangement of periflagellar platelets are very similar to that of $P$. consutum with a platelet "a" split in two parts. However, the right valve of $P$.

317 bimaculatum is not as deeply excavated as in P. consutum and the apical ridge is shorter.

318 Similarly, the periflagellar platelets " $\mathrm{a}_{1}$ " and "d" in P. consutum form posteriorly extensions

319 which overlap the pore area and hide the structures located underneath (Chomérat et al. 2010). The molecular genetic phylogenies inferred in this study are congruent with most 321 previous works on the genus Prorocentrum, and the split in two lineages has been found in 322 most of previous studies using ribosomal genes (Grzebyk et al. 1998, Saldarriaga et al. 2004, 323 Murray et al. 2007, Faust et al. 2008, Hoppenrath and Leander 2008, Chomérat et al. 2010).

324 The clade 1 groups mostly asymmetric species, or those with a variable morphology, living in 325 plankton or sand-dwelling while the clade 2 includes symmetric species, mostly sand326 dwelling (Faust et al. 2008, Hoppenrath and Leander 2008). This result seemed to indicate 327 that the genus Prorocentrum is polyphyletic, and in phylogenies inferred from SSU rDNA, 328 Murray et al. (2009) found that it was paraphyletic due to the presence of several intruders. 329 These findings may argue in favour of the reinstatement of Exuviaella, as proposed by 330 McLachlan et al. (1997). However, this suggestion has not been followed by taxonomists and, 331 from a morphological point of view, there are presumptions that Prorocentrum form a 332 monophyletic group in the evolution of dinoflagellates (Taylor 1980, Fensome et al. 1993). 333 The finding based on molecular analyses, that the group may be polyphyletic and that, by 334 implication, that the peculiar morphology of prorocentroid taxa may be an homoplasious 335 character in dinoflagellates, has appeared puzzling and inexplicable (Murray et al. 2009). The 336 monophyly of the genus has been demonstrated only recently, using multi-genes approaches 
(Zhang et al. 2007) and including non nuclear genes such as mitochondrial genes like cox 1

338 (Murray et al. 2009).

Since the sequence of Prorocentrum consutum isolated from Kuwait grouped with

340 high support with the sequence from Brittany in our SSU rDNA phylogeny, this species is

341 identified unequivocally. The molecular characterization of this species confirms its

342 morphological identification and first report in another location than the type locality (Al-

343 Yamani and Saburova 2010a). Although P. consutum was originally described from a

344 temperate oceanic area (Chomérat et al. 2010), it appears from this study that it is also present

345 in Kuwait where the climate is typically arid and warm (BWh type in Köppen's classification,

346 Peel et al. 2007). Thus, the distribution of this species is not restricted to the temperate area

347 but it is probably widespread. In the phylogenetic analyses, Prorocentrum bimaculatum

348 appeared to be more closely related to P. consutum than to any other species of the clade 2 ,

349 which is consistent with the results obtained with morphology. However, its branch length

350 was rather long, indicating several differences between these two species which probably

351 evolved separately for a long period.

352 The capability to synthesize toxins appears to have arisen early in prorocentroid 353 evolution, and, in particular okadaic acid synthesis is present in several species of the clade 2 354 (Murray et al. 2009). At present, no study of any harmful effects by P. bimaculatum and $P$. 355 consutum (Chomérat et al. 2010) have been undertaken as cultures of these two species are 356 not available yet. However, the production of lipophilic toxins (also known as diarrhetic 357 shellfish poisons, DSP) such as okadaic acid and fast-acting toxins has been demonstrated for 358 all the closely related species in the clade 2, including $P$. arenarium, $P$. belizeanum, $P$. 359 hoffmannianum, P. lima and P. maculosum (Faust and Gulledge 2002). In addition, some 360 other species of the other subclade of clade 2, including $P$. concavum, $P$. faustiae and $P$. levis 361 are also known to produce DSP toxins (Faust and Gulledge 2002, Faust et al. 2008) but no 
data are available for the unidentified strains (Murray et al. 2009). Consequently, from their

363 phylogenetic relationships $P$. bimaculatum and $P$. consutum could be considered as potential

364 toxin-producers and it would be of an utmost importance to assess their actual capability to 365 synthesize lipophilic toxins in a near future.

\section{Acknowledgements}

368 We extend special thanks to Audrey Duval for her help in the search of very rare cells of $P$. 369 bimaculatum and Nicolas Gayet for his skilled assistance with SEM. We are grateful to Dr.

370 Alain Couté for translating the description into Latin and to Sylviane Boulben and Karine 371 Chèze for their contribution to the molecular work. We would like to express thanks to Dr. 372 Igor Polikarpov for his valuable support and suggestions.

\section{References}

Al-Yamani, F. Y. \& Saburova, M. 2010a. Illustrated guide on the flagellates of Kuwait's intertidal soft sediments. Kuwait Institute for Scientific Research, Safat, Kuwait, 197 pp.

Al-Yamani, F. Y. \& Saburova, M. 2010b. First report of ciguatera-associated dinoflagellates in Kuwait's marine environment (abstract). GEOHAB Open Science Meeting on HABs in benthic systems. Honolulu, Hawaii, USA, 21-23 June 2010. p. 23.

Al-Yamani, F. Y., Bishop, J., Ramadhan, E., Al-Husaini, M. \& Al-Ghadban, A. N. 2004. Oceanographic atlas of Kuwait's waters. Kuwait Institute for Scientific Research, Kuwait, 203 pp.

Chomérat, N. \& Couté, A. 2008. Protoperidinium bolmonense sp. nov. (Peridiniales, Dinophyceae), a small dinoflagellate from a brackish hypereutrophic lagoon (South of France). Phycologia 47:392-403. 
Chomérat, N., Sellos, D. Y., Zentz, F. \& Nézan, E. 2010. Morphology and molecular phylogeny of Prorocentrum consutum sp. nov. (Dinophyceae), a new benthic dinoflagellate from South Brittany (northwestern France). J. Phycol. 46:183-94.

Edgar, R. C. 2004. MUSCLE: multiple sequence alignment with high accuracy and high throughput. Nucleic Acids Res. 32:1792-97.

Faust, M. A. 1990. Morphologic details of six benthic species of Prorocentrum (Pyrrophyta) from a mangrove island, Twin Cays, Belize, including two new species. J. Phycol. 26:548-58.

Faust, M. A. 1993a. Prorocentrum belizeanum, Prorocentrum elegans, and Prorocentrum caribbaeum, three new benthic species (Dinophyceae), from a mangrove island, Twin Cays, Belize. J. Phycol. 29:100-07.

Faust, M. A. 1993b. Three new benthic species of Prorocentrum (Dinophyceae) from Twin Cays, Belize: P. maculosum sp. nov., P. foraminosum sp. nov. and P. formosum sp. nov. Phycologia 32:410-18.

Faust, M. A. 1994. Three new benthic species of Prorocentrum (Dinophyceae) from Carrie Bow Cay, Belize: P. sabulosum sp. nov., P. sculptile sp. nov. and P. arenarium sp. nov. J. Phycol. 30:755-63.

Faust, M. A. \& Gulledge, R. A. 2002. Identifying harmful marine dinoflagellates. Smithsonian Institution. Contributions from the United States National Herbarium 42:1-144.

Faust, M. A., Vandersea, M. W., Kibler, S. R., Tester, P. A. \& Litaker, R. W. 2008. Prorocentrum levis, a new benthic species (Dinophyceae) from a mangrove island, Twin Cays, Belize. J. Phycol. 44:232-40.

Felsenstein, J. 1985. Confidence limits on phylogenies: An approach using the bootstrap. Evolution 39:783-91. 
412 Fensome, R. A., Taylor, F. J. R., Norris, D. R., Sargeant, W. A. S., Wharton, D. I. \& Williams, G. L. 1993. A classification of living and fossil dinoflagellates. Micropaleontol. Spec. Publ. 7:1-351.

Grzebyk, D., Sako, Y. \& Berland, B. 1998. Phylogenetic analysis of nine species of Prorocentrum (Dinophyceae) inferred from 18S ribosomal DNA sequences, morphological comparisons, and description of Prorocentrum panamensis, sp. nov. J. Phycol. 34:1055-68.

Guindon, S. \& Gascuel, O. 2003. A simple, fast, and accurate algorithm to estimate large phylogenies by maximum likelihood. Syst. Biol. 52:696-704.

Hoppenrath, M. \& Leander, B. S. 2008. Morphology and molecular phylogeny of a new marine sand-dwelling Prorocentrum species, P. tsawwassenense (Dinophyceae, Prorocentrales), from British Columbia, Canada. J. Phycol. 44:451-66.

McLachlan, J.-L., Boalch, G. T. \& Jahn, R. 1997. Reinstatement of the genus Exuviaella (Dinophyceae, Prorocentrophycidae) and an assessment of Prorocentrum lima. Phycologia 36:38-46.

Mohammad-Noor, N., Moestrup, Ø. \& Daugbjerg, N. 2007a. Light, electron microscopy and DNA sequences of the dinoflagellate Prorocentrum concavum (syn. P. arabianum) with special emphasis on the periflagellar area. Phycologia 46:549-64.

Mohammad-Noor, N., Daugbjerg, N., Moestrup, Ø. \& Anton, A. 2007b. Marine epibenthic dinoflagellates from Malaysia - a study of live cultures and preserved samples based on light and scanning electron microscopy. Nord. J. Bot. 24:629-90.

Murray, S., Nagahama, Y. \& Fukuyo, Y. 2007. Phylogenetic study of benthic, spine-bearing prorocentroids, including Prorocentrum fukuyoi sp. nov. Phycol. Res. 55:91-102. 
Murray, S., Ip, C. L. C., Moore, R., Nagahama, Y. \& Fukuyo, Y. 2009. Are prorocentroid dinoflagellates monophyletic? A study of 25 species based on nuclear and mitochondrial genes. Protist 160:245-64.

Nagahama, Y., Murray, S., Tomaru, A. \& Fukuyo, Y. 2011. Species boundaries in the toxic dinoflagellate Prorocentrum lima (Dinophyceae, Prorocentrales), based on morphological and phylogenetic characters. J. Phycol. 47:178-89.

Peel, M. C., Finlayson, B. L. \& McMahon, T. A. 2007. Updated world map of the KöppenGeiger climate classification. Hydrol. Earth Syst. Sci. 11:1633-44.

Polikarpov, I., Saburova, M. \& Al-Yamani, F. Y. 2010. Biodiversity of Kuwait's benthic dinoflagellates with emphasis on potentially toxic species (abstract). GEOHAB Open Science Meeting on HABs in benthic systems. Honolulu, Hawaii, USA, 21-23 June 2010. p. 30.

Posada, D. 2008. jModelTest: Phylogenetic model averaging. Mol. Biol. Evol. 25:1253-56.

Rasband, W. S. 1997-2006. ImageJ. 1.37c. National Institutes of Health. Bethesda, Maryland.

Ronquist, F. \& Huelsenbeck, J. P. 2003. MrBayes 3: Bayesian phylogenetic inference under mixed models. Bioinformatics 19:1572-74.

Saburova, M., Al-Yamani, F. \& Polikarpov, I. 2009. Biodiversity of free-living flagellates in Kuwait's intertidal sediments. In Krupp, F., Musselman, L.J., Kotb, M.M.A \& Weidig, I. (Eds) Environment, Biodiversity and Conservation in the Middle-East. Proceedings of the First Middle Eastern Biodiversity Congress. Aqaba, Jordan, 20-23 October 2008. Biorisk 3:97-110.

Saldarriaga, J. F., Taylor, F. J. R., Cavalier-Smith, T., Menden-Deuer, S. \& Keeling, P. J. 2004. Molecular data and the evolutionary history of dinoflagellates. Eur. J. Protistol. 40:85-111. 
459 Swofford, D. L. 2002. PAUP* beta version. Phylogenetic analysis using parsimony (*and 460 other methods). v. 4b4-10. Sinauer Associated. Sunderland, MA.

461 Tamura, K., Dudley, J., Nei, M. \& Kumar, S. 2007. MEGA4: Molecular Evolutionary 462 Genetics Analysis (MEGA) software version 4.0. Mol. Biol. Evol. 24:1596-99.

463 Taylor, F. J. R. 1980. On dinoflagellate evolution. Biosystems 13:65-108.

464 Uhlig, G. 1964. Eine einfache Methode zur Extraktion der vagilen mesopsammalen 465 Mikrofauna. Helgol. Wiss. Meeresunters. 11:178-85.

466 Zhang, H., Bhattacharya, D. \& Lin, S. 2007. A three-gene dinoflagellate phylogeny suggests 467 monophyly of Prorocentrales and a basal position for Amphidinium and Heterocapsa. 468 J. Mol. Evol. 65:463-74.

469 470 


\section{Figure legends}

472 Fig. 1. Map of the Arabian Gulf (top), with inset showing Kuwait's shore, where sampling area was located and map of the Kuwait (lower) showing sampling sites examined; white

474 dots: sampling sites for dinoflagellates surveys (2005-2010), black dots: sampling sites, 475 where P. bimaculatum sp. nov. was recorded (May-June 2010), arrow points to type locality 476 of $P$. bimaculatum sp. nov.

Figs 2-7. Light micrographs of Prorocentrum bimaculatum sp. nov. Fig. 2. Living cell in right valve view, with a visible round pusule (pu) near the apex. Fig. 3. The same cell in left valve view. Fig. 4. Cell fixed in Lugol's solution, with a clear area corresponding to the 481 nucleus (n). Fig. 5. DAPI-stained cell observed in epifluorescence, showing the large and 482 chestnut-shaped nucleus. Fig. 6. Right valve of a specimen after dissection (DIC) showing the 483 pore pattern and the two circular patches without ornamentation, the cell content was used for molecular analysis. Fig. 7. Left valve of the same specimen showing the pore pattern and the two circular patches without ornamentation (DIC). Scale bars, $=10 \mu \mathrm{m}$

Figs 8-15. Scanning electron micrographs of Prorocentrum bimaculatum sp. nov. Fig. 8. 488 Right valve view of the holotype specimen (SEM stub CEDiT2010H6) showing the pattern of 489 pores and the two circular patches without ornamentation, the row of marginal pores and the 490 excavation of the periflagellar area. Fig. 9. Left valve view of an isotype specimen, showing 491 the row of marginal pores, and the pores pattern with the two circular patches without 492 ornamentation. Fig. 10. Side view of the holotype specimen, showing the sagittal suture of 493 valves. Fig. 11 Anterior view showing the excavation of the triangular periflagellar area. Fig. 494 12. Detail of the thecal surface with pores and smooth intercalary band. Fig. 13. Detail of the 495 periflagellar area of an isotype specimen (SEM stub CEDiT2010I7). Fig. 14. Detail of the 
nine periflagellar platelets and the two pores seen from the inside. Fig. 15. Detail of the thecal surface and pores seen from the inside of a valve. Scale bars, $20 \mu \mathrm{m}$ in Figs $8-10,10 \mu \mathrm{m}$ in Fig. 11, $5 \mu \mathrm{m}$ in Figs 12, 15 and $2 \mu \mathrm{m}$ in Fig. 14.

499

Figs 16-17. Scanning electron micrographs of Prorocentrum bimaculatum sp. nov. Fig. 16.

501 Left valve view of a young cell with a thin theca, with two kinds of thecal pores, large and 502 small. Fig. 17. Detail of the pores in the central area of the valves with small pores present 503 (arrows). Scale bars, $20 \mu \mathrm{m}$ in Fig. 15 and $5 \mu \mathrm{m}$ in Fig. 16.

504

Figs 18-21. Line drawings of Prorocentrum bimaculatum sp. nov. Fig. 18. Right valve view.

Fig. 19. Left valve view. Fig. 20. Detail of the periflagellar platelets as seen in apical view.

Fig. 21. Interpretation of the arrangement of periflagellar platelets and pores, redrawn from SEM observations. Plain lines indicate actual sutures of the platelets, dotted lines indicate the margin of the extensions of some platelets which partially hide a part of the periflagellar area. Scale bars, $20 \mu \mathrm{m}$ in Figs $18-19$ and $5 \mu \mathrm{m}$ in Figs $20-21$.

Fig. 22. ML phylogenetic trees inferred from SSU rDNA and LSU rDNA. (A) ML tree of Prorocentrum species inferred from a SSU rDNA data matrix (34 taxa, 1712 characters). The Likelihood value was found to be loglk $=-6760.32692$. The tree was rooted using Scrippsiella sequences as outgroup. ML analysis was constrained by user-specified settings obtained from

516 jModelTest; model selected: $\mathrm{GTR}+\mathrm{I}+\Gamma_{4}$. Substitution rate matrix: $\mathrm{A} \leftrightarrow \mathrm{C}=1.06439, \mathrm{~A} \leftrightarrow \mathrm{G}=$ 3.73789, $\mathrm{A} \leftrightarrow \mathrm{T}=1.05823, \mathrm{C} \leftrightarrow \mathrm{G}=0.42569, \mathrm{C} \leftrightarrow \mathrm{T}=8.57948$, against $\mathrm{G} \leftrightarrow \mathrm{T}$ set to 1.00000 (fixed). Assumed nucleotide frequencies: $f(A)=0.26184, f(C)=0.20010, f(G)=0.26347$, $f(T)=0.27459$. Among-site rate variation: assumed proportion of invariable sites: $I=0.504$. 
521 Bootstrap values of ML (1000 replicates), posterior probabilities of BI $(2,000,000$ generations) and bootstrap values of MP (1000 replicates) are shown at nodes in order from left to right, irresolutions noted with '-‘. (B) ML tree inferred from a LSU rDNA data matrix

524 (26 taxa, 967 characters). The Likelihood value was found to be loglk $=-5884.81206$. The 525 tree was rooted using Scrippsiella sequences as outgroup. ML analysis was constrained by 526 user-specified settings obtained from jModelTest; model selected: TN93. Assumed nucleotide 527 frequencies: $\mathrm{f}(\mathrm{A})=0.22081, \mathrm{f}(\mathrm{C})=0.23378, \mathrm{f}(\mathrm{G})=0.27628, \mathrm{f}(\mathrm{T})=0.26913$. Among-site rate 528 variation: assumed proportion of invariable sites: $\mathrm{I}=0.149$. Rates at variable site assumed to 529 be gamma distributed with shape parameter: $\alpha=0.793$. Bootstrap values of ML (1000 530 replicates), posterior probabilities of BI (2,000,000 generations) and bootstrap values of MP 531 (1000 replicates) are shown at nodes in order from left to right, irresolutions noted with '-'. 
Table 1 : Comparison of morphological features of six benthic Prorocentrum species related to P. bimaculatum sp. nov., and placed in the same subclade of clade 2 in the phylogenetic analyses.

\begin{tabular}{|c|c|c|c|c|c|c|c|}
\hline & $\begin{array}{l}\text { P. bimaculatum sp. nov. } \\
\text { Chomérat et Saburova }^{\mathrm{a}}\end{array}$ & $\begin{array}{l}\text { P. consutum } \\
\text { Chomérat et Nézan }^{\mathrm{b}}\end{array}$ & $\begin{array}{l}\text { P. arenarium } \\
\text { Faust }^{\mathrm{c}} \mathrm{d}, \mathrm{e}, \mathrm{f}\end{array}$ & $\begin{array}{l}\text { P. lima } \\
\text { (Ehrenberg) Stein }{ }^{\mathrm{d}, \mathrm{e}, \mathrm{f}}\end{array}$ & $\begin{array}{l}\text { P. belizeanum } \\
\text { Faust }^{\mathrm{d}, \mathrm{g}, \mathrm{h}}\end{array}$ & $\begin{array}{l}\text { P. hoffmannianum } \\
\text { Faust }^{\mathrm{d}, \mathrm{i}}\end{array}$ & $\begin{array}{l}\text { P. maculosum } \\
\text { Faust }^{\mathrm{j}}\end{array}$ \\
\hline Cell shape & Oblong oval & $\begin{array}{l}\text { Subcircular to broadly } \\
\text { ovoid }\end{array}$ & Round to slight oval & Ovoid & Round to slight oval & Ovoid & Oval \\
\hline Cell size $[\mu \mathrm{m}]$ & $\begin{array}{l}\text { L: 49.9-55.3, } \\
\text { W: } 38.4-43.2\end{array}$ & $\mathrm{~L}: 57-61, \mathrm{~W}: 52-55$ & $\begin{array}{l}\text { L: } 30-32, \mathrm{~W}: 30-32^{\mathrm{c}, \mathrm{d}} \\
\text { D: } 36-42^{\mathrm{e}} \\
\text { D: } 42-45^{\mathrm{f}}\end{array}$ & $\begin{array}{l}\text { L: } 31-47, \mathrm{~W}: 22-40^{\mathrm{d}} \\
\text { L: } 41-43 ; 31-32^{\mathrm{e}} \\
\text { L: } 38-45, \mathrm{~W}: 27-38^{\mathrm{f}}\end{array}$ & L: $55-60, \mathrm{~W}: 50-55$ & $\begin{array}{l}\text { L: } 45-55, \mathrm{~W}: 40- \\
45\end{array}$ & $\begin{array}{l}\mathrm{L}: 40-50, \mathrm{~W}: 30- \\
40\end{array}$ \\
\hline Theca ornamentation & $\begin{array}{l}\text { Smooth with two circular } \\
\text { patches devoid of pores }\end{array}$ & $\begin{array}{l}\text { Smooth with a ring of } \\
\text { marginal areolae }\end{array}$ & Smooth & Smooth & Areolate & Areolate & Rugose \\
\hline Pyrenoid & not observed (?) & Yes, central & Yes, central & Yes, central & Yes, central & Yes, central & Yes, central \\
\hline Nucleus & $\begin{array}{l}\text { Chestnut-shaped, } \\
\text { posterior }\end{array}$ & $\begin{array}{l}\text { Kidney-shaped, } \\
\text { posterior }\end{array}$ & ?, posterior & Round, posterior & $\begin{array}{l}\text { Kidney-shaped, } \\
\text { posterior }\end{array}$ & Large, posterior & Large, posterior \\
\hline Periflagellar area & & & & & & & \\
\hline Ridge on left valve & Present, short & Present & Absent & Absent & Present & Present & Absent \\
\hline No. platelets & 9 & 9 & $?$ & 8 & $?$ & 8 & 8 \\
\hline periflagellar collar & Absent & Present & Absent & Present & Present & Present & Present \\
\hline
\end{tabular}


Pores

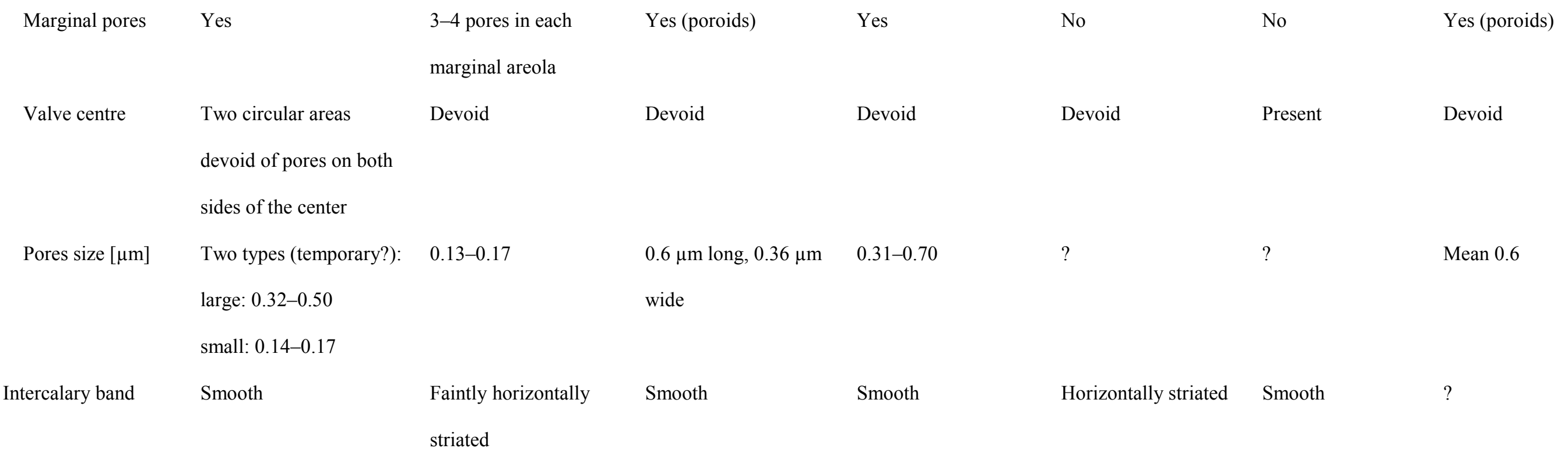

$\mathrm{L}=$ length; $\mathrm{W}=$ width; $\mathrm{D}=$ diameter; $?=$ no data available; $(?)=$ to be confirmed

References : ${ }^{\mathrm{a}}$ this study, ${ }^{\mathrm{b}}$ Chomérat et al. (2010), ${ }^{\mathrm{c}}$ Faust (1994), ${ }^{\mathrm{d}}$ Faust and Gulledge (2002), ${ }^{\mathrm{e}}$ Grzebyk et al. (1998), ${ }^{\mathrm{f}}$ Mohammad-Noor et al. (2007b),

${ }^{\mathrm{g}}$ Faust (1993a), ${ }^{\mathrm{h}}$ Faust et al. (2008), ${ }^{\mathrm{i}}$ Faust (1990), ${ }^{\mathrm{j}}$ Faust (1993b). 


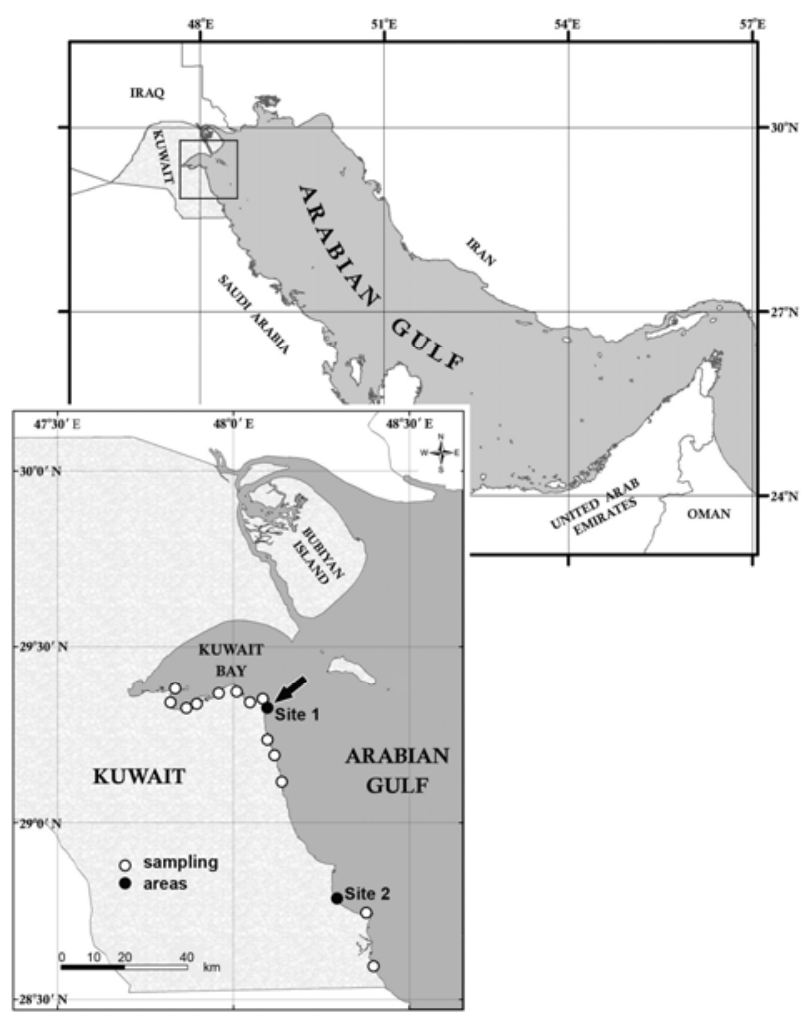

Fig. 1 

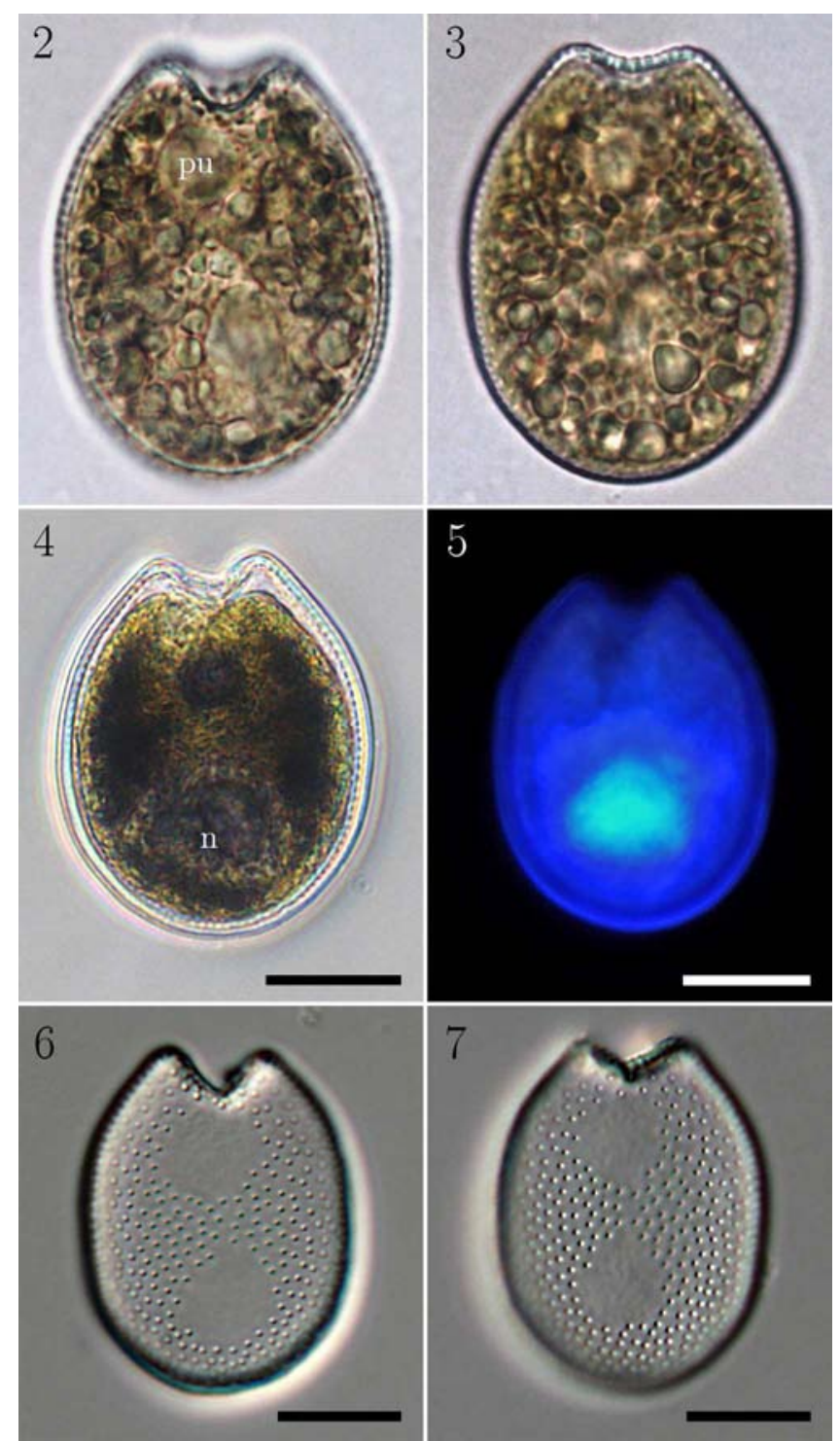

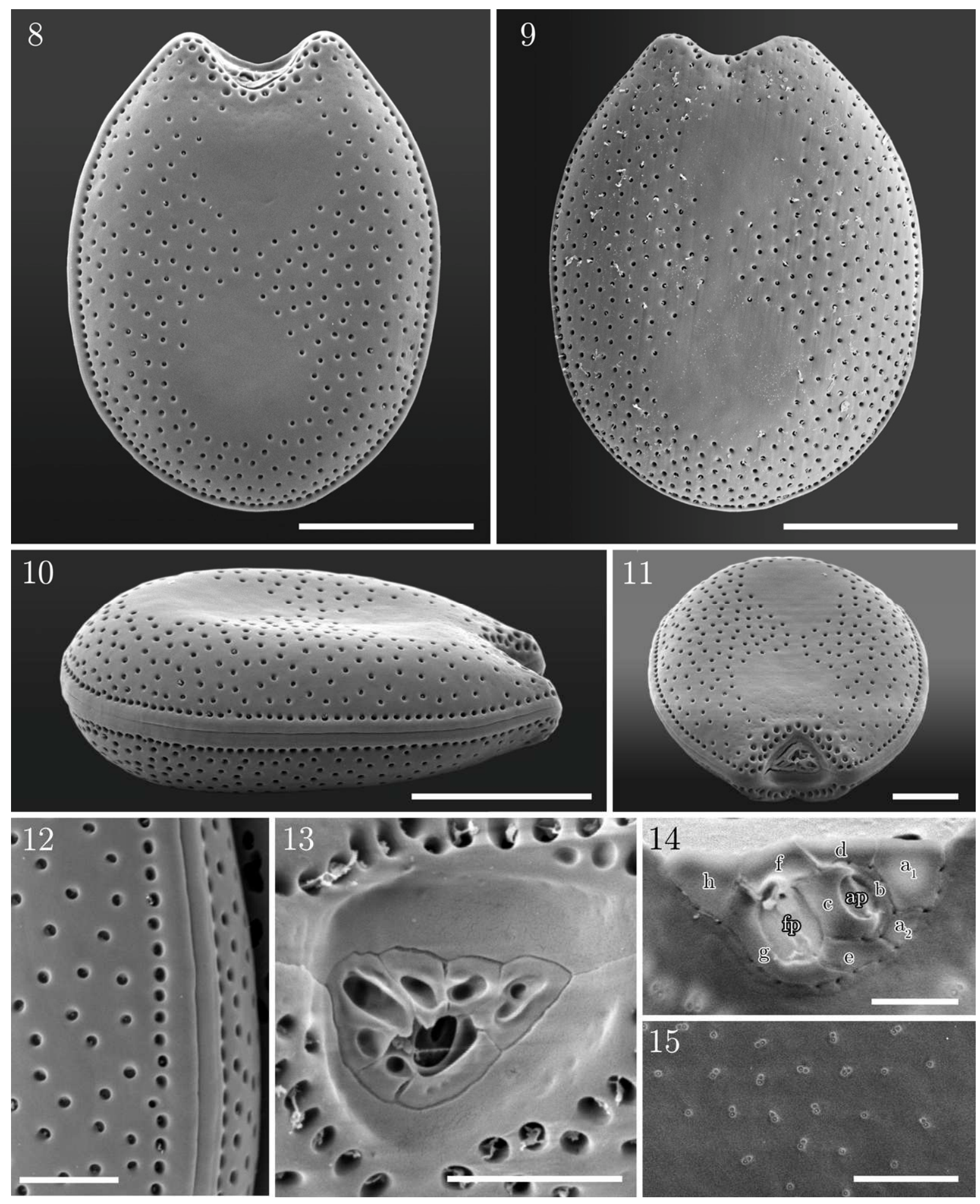


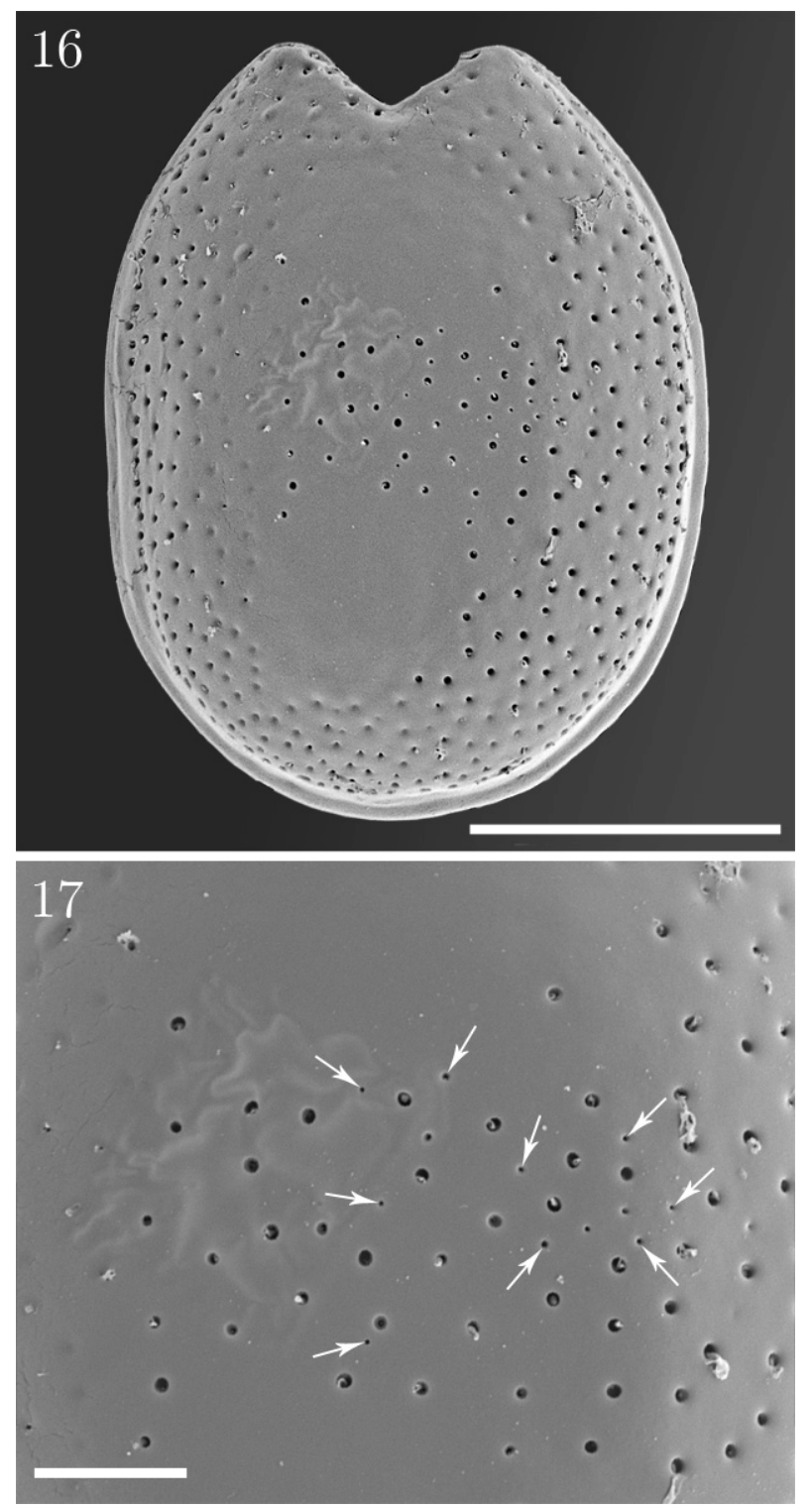



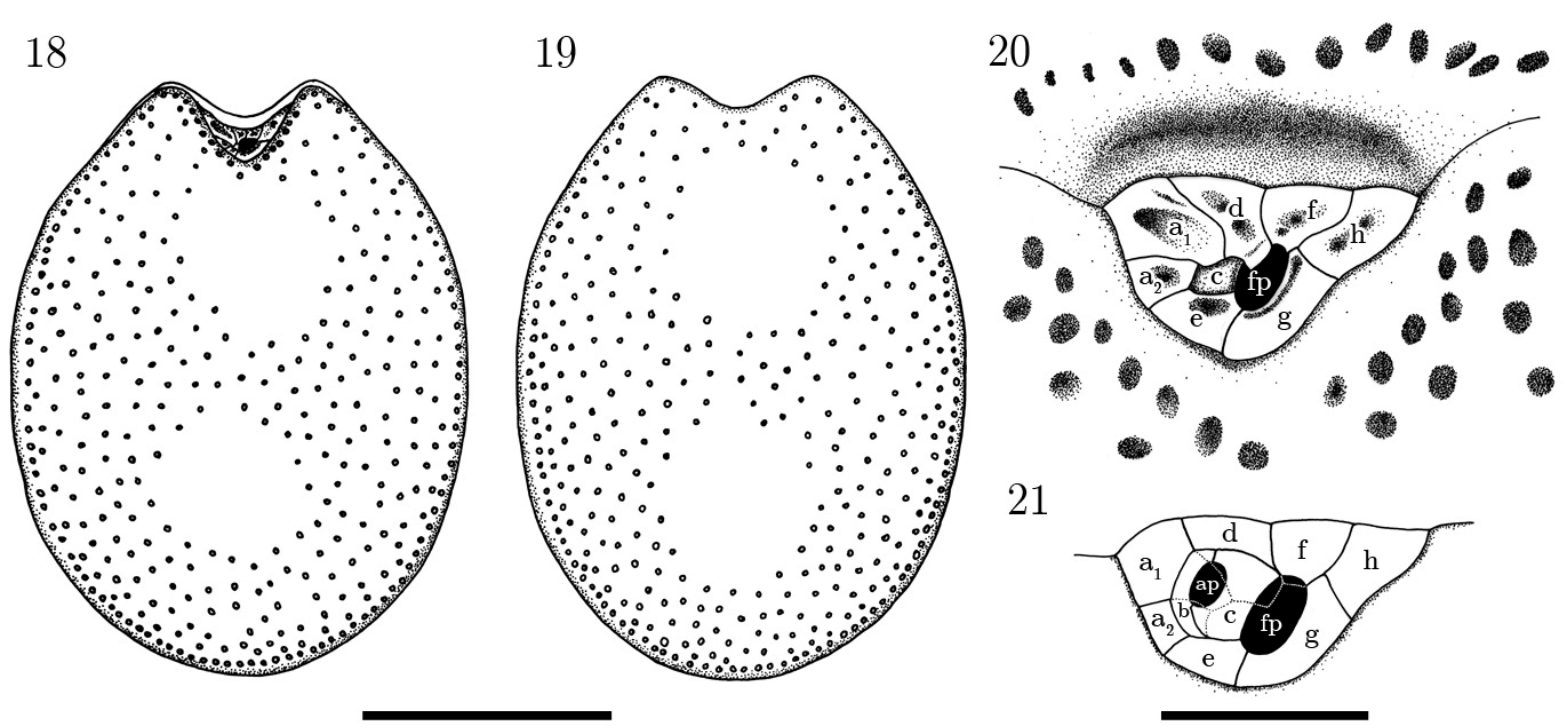
A

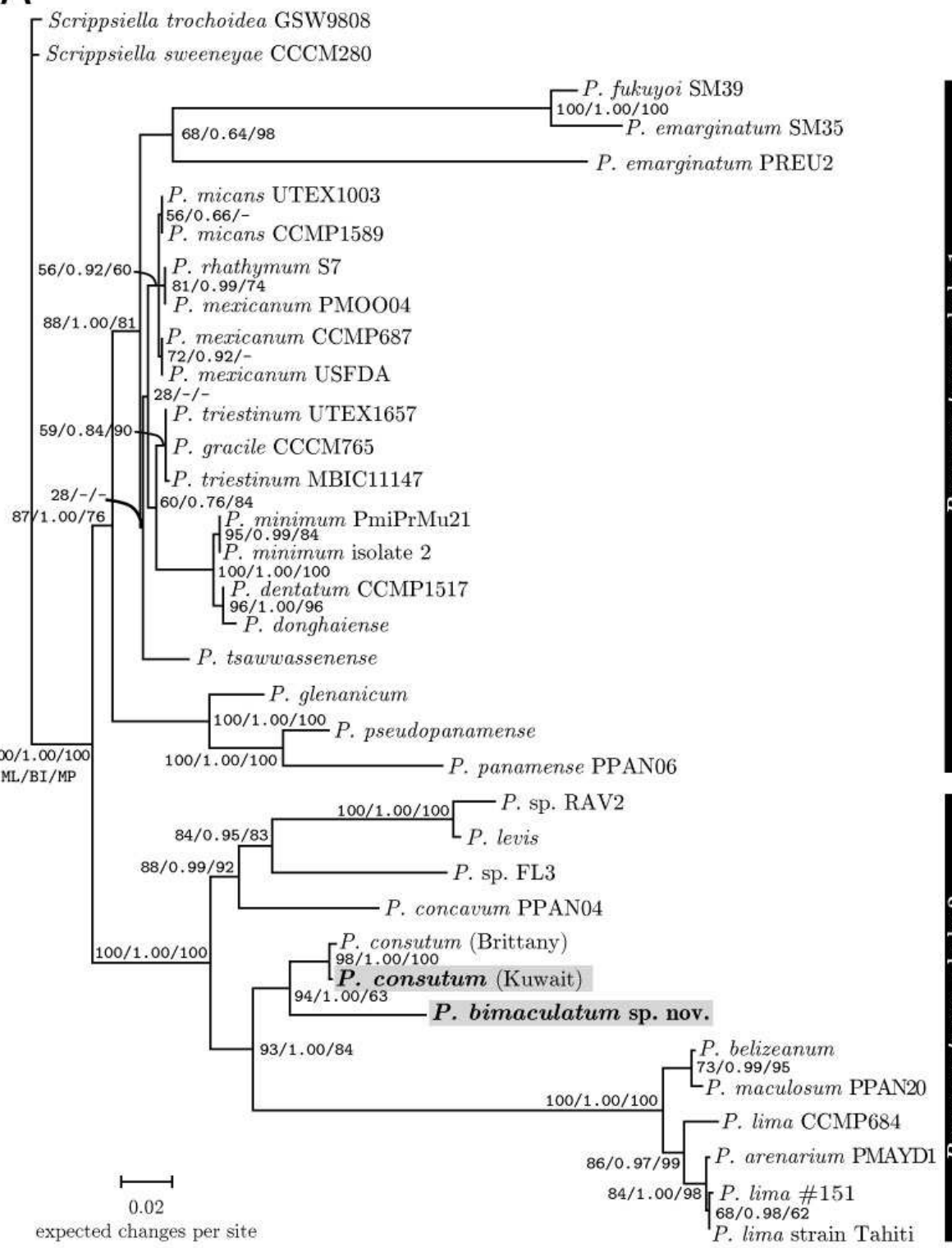

B

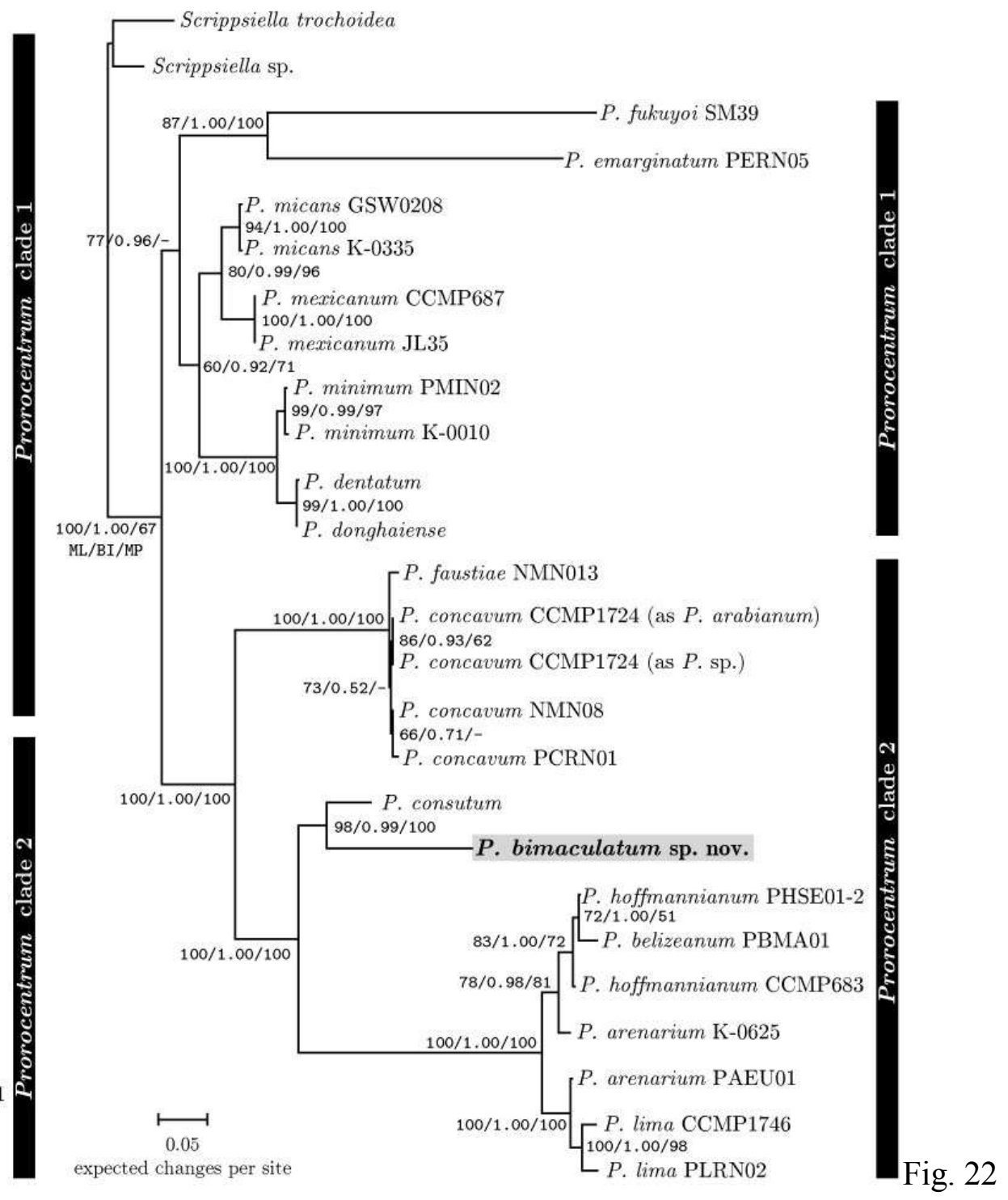

